\title{
PERANCANGAN SISTEM PERINGATAN DINI MENGUNAKAN TOGAF
}

\author{
Sintaria Br Sembiring \\ Fakulatas Teknologi Informasi, Universitas Advent Indonesia
}

\begin{abstract}
Abstrak
Letak geografis Indonesia menyebabkan Indonesia merupakan negara dengan tingkat kejadian bencana yang sangat tinggi. Selain menimbulkan kerugian material, bencana juga menyebabkan korban jiwa. Karena itu, bencana harus ditangani dengan baik untuk meminimalisasi resiko yang ditimbulkan. Namun pada kenyataannya, kurangnya dan ketidakakuratan data dan informasi menyebabkan proses pengambilan keputusan yang lambat. Penelitian ini bertujuan untuk membuat perencanaan arsitektur sistem informasi penanggulangan bencana menggunakan Framework TOGAF dengan studi kasus di Badan Penanggulangan Bencana Daerah Propinsi Jawa Barat(BPBD). Arsitektur sistem informasi yang dikembangkan pada penelitian ini merupakan tool yang dapat digunakan oleh BPBD untuk mengembangkan dan mengelola sistem informasi untuk penanggulangan bencana. Penelitian ini menghasilkan arsitektur sistem informasi yang dimodelkan dengan arsitektur bisnis, arsitektur aplikasi, arsitektur data, arsitektur teknologi, evaluasi gap, dan rencana migrasi. Pemodelan arsitektur enterprise dibuat untuk menghasilkan blueprint pengembangan sistem informasi untuk penanggulangan bencana. Kata Kunci: Arsitektur enterprise, TOGAF, Framework, penanggulangan bencana, sistem informasi
\end{abstract}

\section{DESIGN OF EARLY WARNING SYSTEM USING TOGAF}

\begin{abstract}
The geographical position of Indonesia led to Indonesia is a country with a very high incidence of disasters. Besides causing material damage, the disaster also caused fatalities. Therefore, the disaster must be handle properly to minimize the risk posed towards constitutions. However in fact, the lack of data and information, and inaccuracies lead to a slow decision-making process. This research aims to make the planning of disaster management information system architecture using the TOGAF Framework with a case study of Regional Disaster Management Agency of West Java. Information system architecture to development in this study is a tool that can used by BPBDs for developing and managing information systems for disaster management. This research resulted in the information system architecture modeled with business architecture, application architecture, data architecture, technology architecture, evaluation gap, and migration plans. Enterprise architecture modeling made to produce blueprint development of information systems for disaster management.

Kata Kunci: Enterprise Architecture, TOGAF, Framework, Disaster Prevention, Information System
\end{abstract}

\section{Pendahuluan}

Secara geologis Indonesia terletak di antara tiga lempeng utama yang ada di dunia yaitu lempeng Indo-Australia, Eurasia dan Pasifik. Ketiga lempeng ini merupakan lempeng aktif yang berarti selalu bergerak dan selalu berinteraksi. Indonesia merupakan daerah yang termasuk dalam wilayah the ring of fire (cincin api), pertemuan lempeng tektonik yang terhampar dengan barisan gunung api dan patahan-patahan gempa yang aktif. Karena ketiga lempeng tersebutlah yang sering mengakibatkan terjadi vulkanisme (gunung api) dan gempa di indonesia. Indonesia adalah negara yang jumlah gunung api yang terbanyak di dunia yaitu sebanyak \pm 100 buah, dibagi dalam 3 kelompok: padam, istirahat dan aktif (Sungkawa, D : 2010). Menurut data di BNPB sejak 2002 sampai 2014 tercatat sebanyak 1093 bencana alam yang terjadi disebabkan oleh bencana hidrometeorologi maupun bencana non 
hidrometeorologi. Dari bencana tersebut tercatat 190.375 jiwa yang meninggal, merusak sarana pendidikan 32.463 unit, rumah ibadah 11.604 unit, sarana kesehatan 4672 unit, dan lahan pertanian 4.721.990 hektare. (www.antarasumbar.com, 22 Februari 2014). Bencana yang terjadi di Jawa Barat disebabkan oleh gempa bumi, letusan gunung api, tsunami, banjir dan lain sebagainya. Menurut BPBD Provinsi Jawa Barat dari bulan Januari - Desember 2013 terjadi bencana sebanyak 1268, perkiraan kerugiaan Rp32.724.210.271.

Permasalahan yang terjadi pada tahap prabencana disebabkan karena keterlambatan informasi akan adanya bencana (peringatan) yang disampaikan kepada masyarakat, sehingga mengakibatkan banyak korban jiwa dan hilang materi yang diakibatkan bencana.

\section{Identifikasi Masalah}

Adapun identifikasi masalah dari penelitian ini yaitu:

1. Bagaimana mengidentifikasi permasalahan yang timbul dalam proses penanggulangan bencana, dan mengidentifikasi solusi yang dapat diberikan oleh sistem informasi yang tersedia saat ini. Dan bagaimana proses penggulangan bencana yang ideal sesuai dengan amanat undang-undang yang berlaku.

2. Bagaimana mengidentifikasi ketersediaan teknologi informasi yang ada saat ini dan trend perkembangan teknologi yang akan datang yang dapat dimanfaatkan untuk membangun sistem penanggulangan bencana.

3. Bagaimana merancang sebuah arsitektur sistem informasi yang sesuai untuk penanggulangan bencana untuk kebutuhan di Indonesia dan sesuai dengan amanat Undang-undang.

\section{Tujuan Penelitian}

Penelitian ini dilakukan untuk tujuan:

1. Mengidentifikasi permasalahan yang sering muncul dalam proses penanggulangan bencana.

2. Mengidentifikasi ketersediaan teknologi yang ada dan peranan sistem informasi dalam penanggulangan bencana di Jawa Barat.

3. Merancang arsitektur sistem informasi untuk penanggulangan bencana di Jawa Barat.

\section{Ruang lingkup penelitian}

Adapun ruang lingkup yang akan dibahas dari penelitian ini yaitu:

1. Untuk membuat perencanaan arsitektur sistem informasi penanggulangan bencana di Indonesia digunakan kerangka kerja The Open Group Architecture Framework (TOGAF).

2. Arsitektur sistem informasi yang dibangun untuk mendukung proses penanggulangan bencana sesuai dengan yang diamanatkan oleh perundang-undangan BNPB.

\section{Metodologi penelitian}

Undang-undang mengamanatkan bahwa proses pra-bencana harus berjalan secara terencana, terkontrol dan profesional. Dukungan teknologi informasi yang ada saat ini memungkinkan tujuan ini dapat dicapai dengan lebih mudah. Karena itu perlu dikembangkan sebuah sistem informasi yang terintegrasi yang sesuai dengan visi, misi, kebutuhan dan strategi bisnis organisasi. Agar proses pengembangan sistem informasi sesuai dengan hal di atas, maka perlu dilakukan terlebih dahulu perencanaan arsitektur sistem informasi. Penelitian ini dilakukan untuk tujuan mengembangan sebuah perencanaan arsitektur sistem informasi menggunakan framework TOGAF.

\section{Proses Bisnis Badan Penanggulangan Bencana Daerah Provinsi Jawa Barat}

Proses bisnis dalam organisasi BPBD dilakukan untuk menyelesaikan permasalahan-permasalahan yang terjadi sebagai dampak terjadinya bencana mulai dari Pra-bencana. Proses bisnis yang akan dibuat dapat mengurangi kerugiaan yang terjadi akibat bencana. 


\section{Peringatan Dini}

Pada tahap peringatan dini dilakukan proses bisnis yang dapat digunakan untuk mengurangi segala kemungkinan yang terjadi akibat dari bencana. Pada tahap ini Pusdalops BPBD melakukan tugasnya sebagai pemantau dalam upaya mitigasi dan kesiapsiagaan. Proses bisnis yang diterapkan dalam melakukan peringatan dini adalah sebagai berikut:

a. Perencanaan penanggulangan bencana

Pada tahap perencanaan dilakukan pengenalan dan pengkajian ancaman bencana, pemahaman tentang kerentanan masyarakat, analisis kemungkinan dampak bencana, pilihan tindakan pengurangan risiko bencana, penentuan mekanisme kesiapan dan penanggulangan dampak bencana, dan alokasi tugas, kewenangan, sumber daya yang tersedia dan melakukan pemantauan dan komunikasi dengan BMKG, PVMBG, Pusdalops PB di daerah lain, dan posko/personil lapangan.

b. Pengurangan resiko bencana

Pengurangan resiko bencana yang terdiri atas: pengenalan dan pemantauan risiko bencana, pengembangan budaya sadar bencana, penerapan upaya fisik, nonfisik, jenis bencana yang mungkin terjadi, waktu dan tempat, jenis kerusakan, kerugian yang akan timbul, sumber daya yang tersedia dan penentuan status keadaan darurat bencana atau tingkat kesiagaan.

c. Pencegahan

Pencegahan terdiri atas: identifikasi dan pengenalan secara pasti terhadap sumber bahaya atau ancaman bencana, kontrol terhadap penguasaan dan pengelolaan sumber daya alam yang secara tiba-tiba dan/atau berangsur berpotensi sumber ancaman atau bahaya bencana, memberikan arahan kepada personil untuk menjamin kelangsungan komunikasi, penataan ruang dan pengelolaan lingkungan hidup, dan penguatan ketahanan sosial masyarakat.

d. Dilakukan pendidikan dan pelatihan kepada masyarakat mengenai bencana.

Pendidikan dan pelatihan kepada masyarakat perlu dilakukan untuk meningkatkan pemahaman masyarakat akan karateristik bencana yang berpotensi terjadi di daerah masing-masing, tandatanda terjadinya bencana yang perlu diwaspadai dan tindakan penyelamatan yang perlu dilakukan bila sebuah bencana berpotensi akan terjadi. Pendidikan dan pelatihan ini perlu untuk mengurangi resiko dampak bencana.

\section{Metode TOGAF ADM}

Penelitian dilakukan di (BPBD) Jawa Barat dengan tujuan untuk mengembangkan sebuah model arsitektur enterprise menggunakan metode TOGAF ADM yang disesuaikan dengan kebutuhan dan keterbatasan yang ada. Penelitian dimulai dengan melakukan studi pustaka, pengumpulan data, pemilihan framework dan seterusnya. Secara lengkap, tahapan dalam penelitian ini ditunjukkan oleh Gambar 1.

Seperti ditunjukkan oleh gambar 1 , penelitian ini dilakukan dengan langkah-langkah sebagai berikut: studi pustaka, pengumpulan data, preliminary : framework and principles, penentuan architecture vision, menentukan business architecture, menentukan information system architecture, menentukan technology architecture, analisa opportunities and solution dan analisa migration planning. 


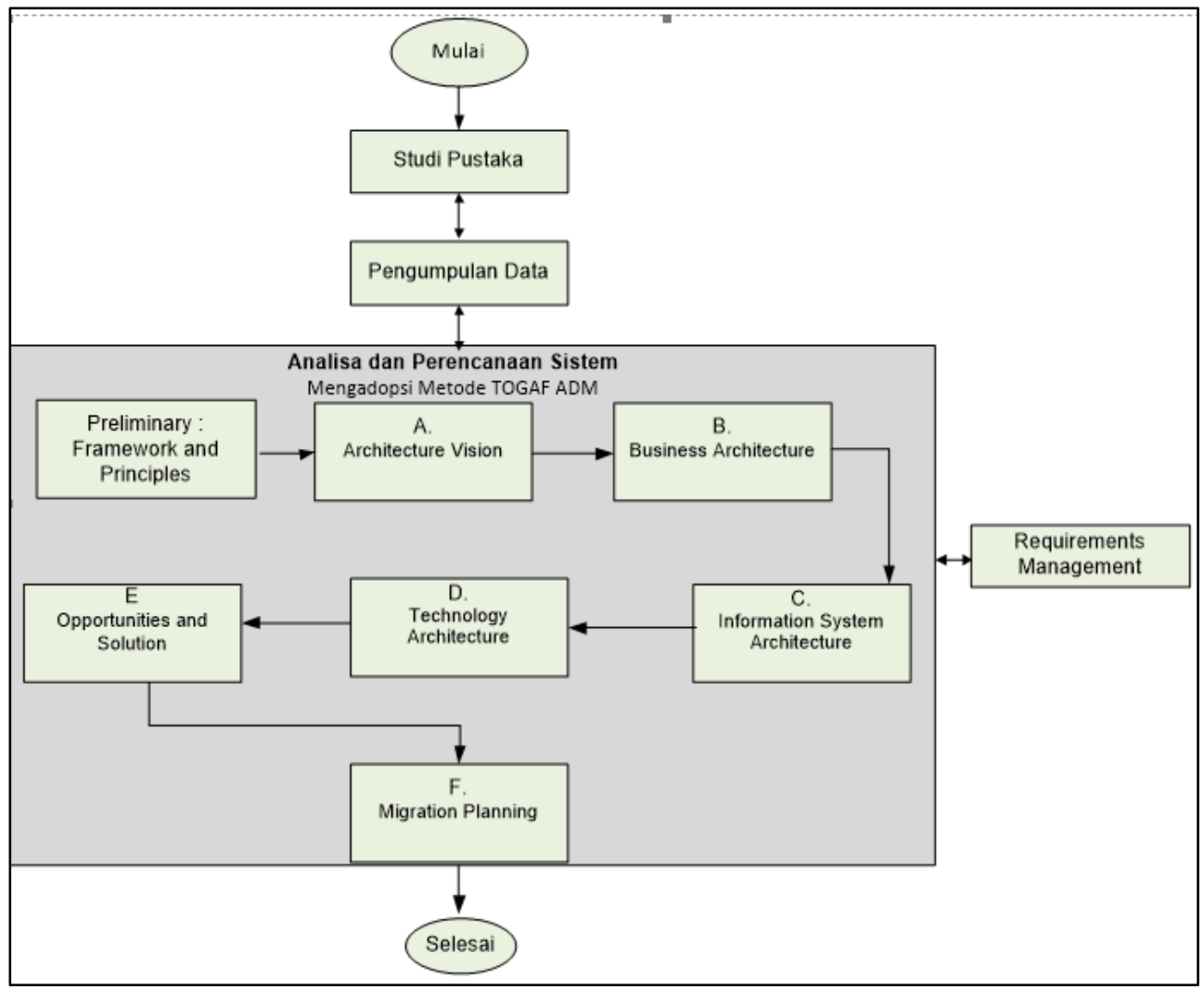

Gambar 1. Langkah-langkah penelitian

\section{Hasil dan Pembahasan}

Setelah melakukan pengumpulan data, menentukan framework pengembangan arsitektur sistem, maka langkah selanjutnya adalah menentukan arsitektur visi dari organisasi yang dikaji.

\section{Fase Architecture Vision}

Fase architecture vision adalah proses untuk menentukan visi, misi, tujuan dan sasaran bisnis dari sebuah proses perencanaan arsitektur enterprise.

\section{Visi dan Misi}

Visi dan misi dalam perancangan arsitektur entreprise sistem peringatan dini: Mengembangkan sebuah sistem informasi yang dapat memberikan layanan berkinerja tinggi untuk mendukung proses penanggulangan bencana yang terencana, terpadu, dan terkoordinasi dan Sistem informasi yang dikembangkan dapat memberikan layanan informasi yang aman, reliable dan terintegrasi sesuai dengan kebutuhan data dan informasi.

\section{Tujuan Bisnis (business goals)}

Untuk mencapai visi dan misi dalam peringatan dini diperlukan tujuan bisnis dari proses pengembangan sistem informasi tersebut, antara lain:

1. Sistem informasi yang dibangun dapat mengurangi dan meminimalisasi jumlah korban jiwa yang terdampak bencana.

2. Sistem informasi yang dibangun dapat menjamin ketersediaan sarana yang dibutuhkan jika bencana terjadi.

\section{Sasaran Bisnis (business objectives)}


Untuk mewujudkan tujuan perencanaan arsitektur enterprise sistem informasi penanggulangan bencana, maka ditetapkan beberapa sasaran bisnis yang perlu dicapai, antara lain:

1. Sistem informasi yang dikembangkan harus dapat mendukung proses manajemen pengadaan, pemeliharaan dan penggunaan yang baik dari sarana dan prasarana penanggulangan bencana.

2. Sistem informasi yang dikembangkan dapat berguna untuk memberikan peringatan dini kepada masyarakat yang berpotensi terdampak sebelum terjadi bencana.

\section{Fase Business Architecture}

Fase busines architecture bertujuan sebagai struktur aktivitas dalam proses bisnis, aliran informasi dan sebagai acuan dalam mencapai persetujuan antara teknologi informasi dan kebutuhan bisnis terhadap teknologi informasi. Untuk mendapatkan pemahaman mengenai bagaimana proses penanggulangan bencana dilakukan dengan menggunakan pemodelan arsitektur bisnis. Tahapan yang dilakukan pada fase business architecture adalah:

\section{Pemodelan bisnis}

Pemodelan bisnis bertujuan untuk menyediakan suatu dasar pengetahuan yang dapat digunakan untuk menetapkan rencana arsitektur bisnis. Proses pringgatan dini pada Pusdalops BPBD propinsi Jawa Barat dilakukan untuk mengidentifikasi aktivitas area fungsional. Identifikasi area fungsional dilakukan untuk memahami fungsi utama yang terkait dengan unit organisasi dan aliran informasi dibuat mengunakan value chain. Pada gambar 2 fungsi-fungsi bisnis di Pusdalops BPBD dikelompokan menjadi 2, yaitu aktivitas pendukung dan aktivitas utama. Aktivitas utama terdiri dari pemetaan geomapping, pengamatan/pemantauan dan pencatatan dan pelaporan. Sedangkan aktivitas pendukung terdiri dari proses bisnis manajemen sumberdaya tim, pengadaan dan pemeliharaan sarana dan prasarana, administrasi dan pengelolaan finansial.

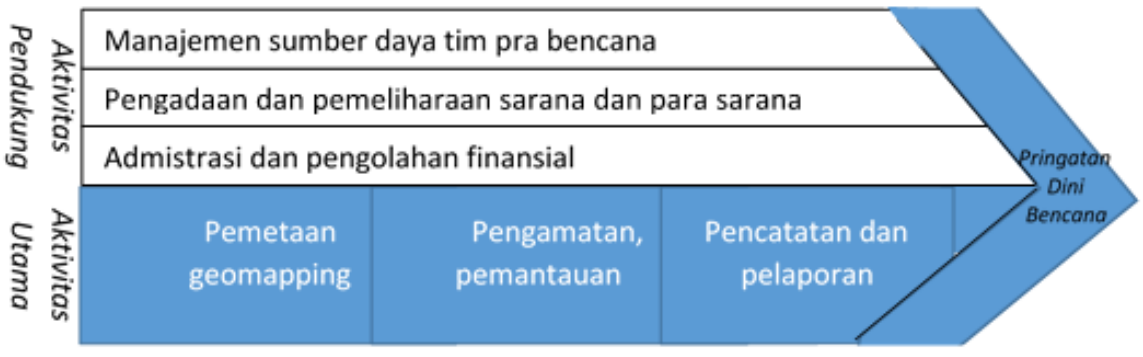

Gambar 2 Value Chain Peringatan dini

\section{Use case peringatan dini}

Peringatan dini bencana merupakan tahapan intraksi antara sistem dan peringatan bencana, Proses peringatan dini yang baik akan dapat mengurangi dampak korban jiwa sebaliknya proses peringatan dini yang kurang baik akan menyebabkan dampak korban jiwa yang lebih besar. Alur diagram use case dimulai dari operator memantau kegiatan pada penanggulangan bencana, apabila ada terdekteksi kemungkinan bencana pihak operator mengirimkan informasi kepada pihak BPBD dan Pusdalops, supaya diambil tindakan yang tepat dalam hal peringatan dini. Use case peringatan dini seperti yang ditunjukkan Gambar 3. 


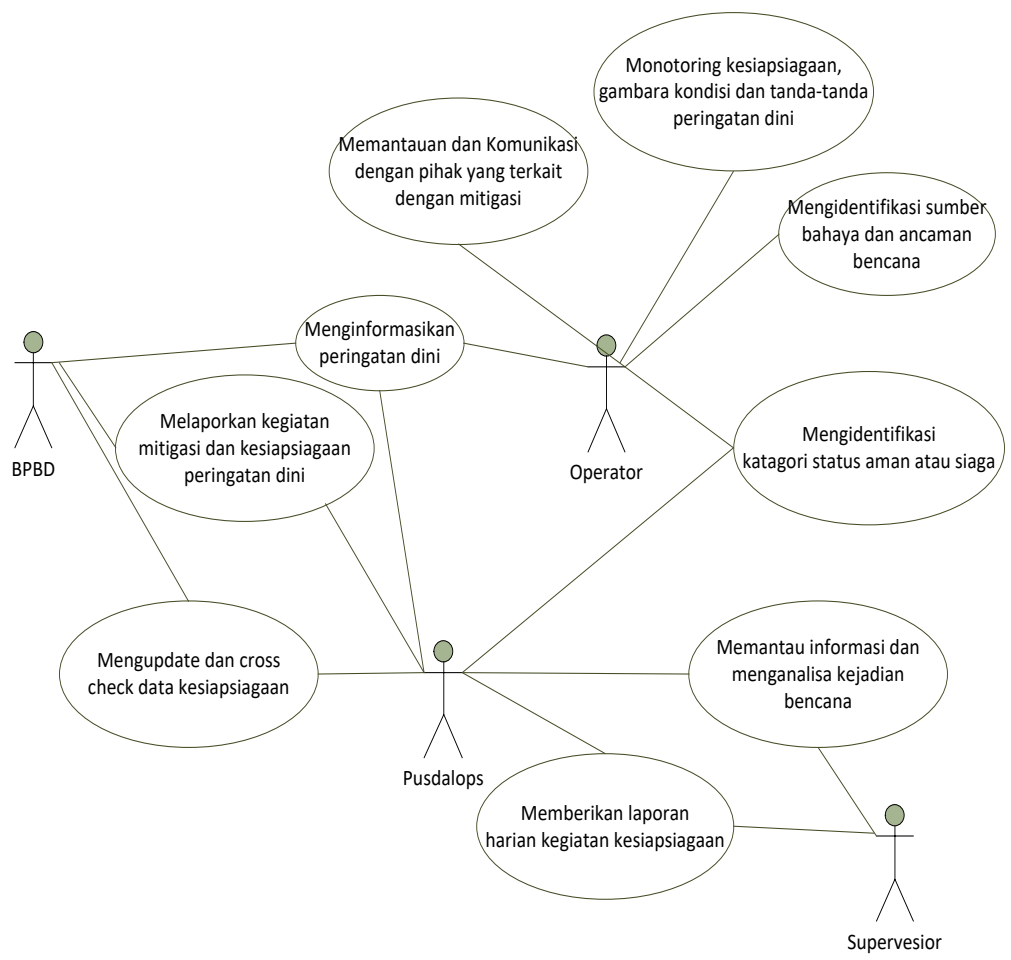

Gambar 3 Use Case peringatan dini bencana

\section{Fase Information System Architecture}

Fase information system architecture bertujuan untuk membuat pemodelan arsitektur sistem informasi. Fase ini terdiri dari 2 (dua) fase pengembangan, yaitu fase pengembangan arsitektur aplikasi dan fase pengembangan arsitektur data. Pada tahap pengembangan arsitektur aplikasi dilakukan identifikasi aplikasi apa saja yang perlu ditambahkan untuk mendukung fungsi bisnis yang ada. Setelah diidentifikasi aplikasi apa saja yang perlu ditambahkan maka didefinisikan hubungan antara aplikasi tersebut dengan fungsi bisnis yang ada. Kandidat aplikasi yang dibutuhkan dapat dilihat pada Tabel 1. di bawah ini.

Tabel 1. Daftar Kandidat Aplikasi

\begin{tabular}{|r|l|l|}
\hline \multicolumn{1}{|c|}{ No } & \multicolumn{1}{|c|}{ Kelompok } & \multicolumn{1}{c|}{ Kandidat Aplikasi } \\
\hline 1 & Sistem Mitigasi dan & Aplikasi Monitoring dan Peringatan Dini \\
& Peringatan Dini & \\
\hline 2 & Sistem Informasi Tanggap & 1. Aplikasi Simulasi dan Asessment \\
& Darurat & Bencana \\
& & 2. Aplikasi Korban dan Kerusakan \\
& & Bencana \\
& & 3. Aplikasi Penanganan Medis dan SAR \\
& & 4. Aplikasi Pengelolaan Relawan \\
\hline
\end{tabular}

Selanjutnya arsitektur data ditentukan dengan menganalisa kebutuhan data dari masing-masing aplikasi. Hubungan antara aplikasi dan kebutuhan data dapat dilihat pada class diagram seperti yang ditunjukkan oleh Gambar 4. 


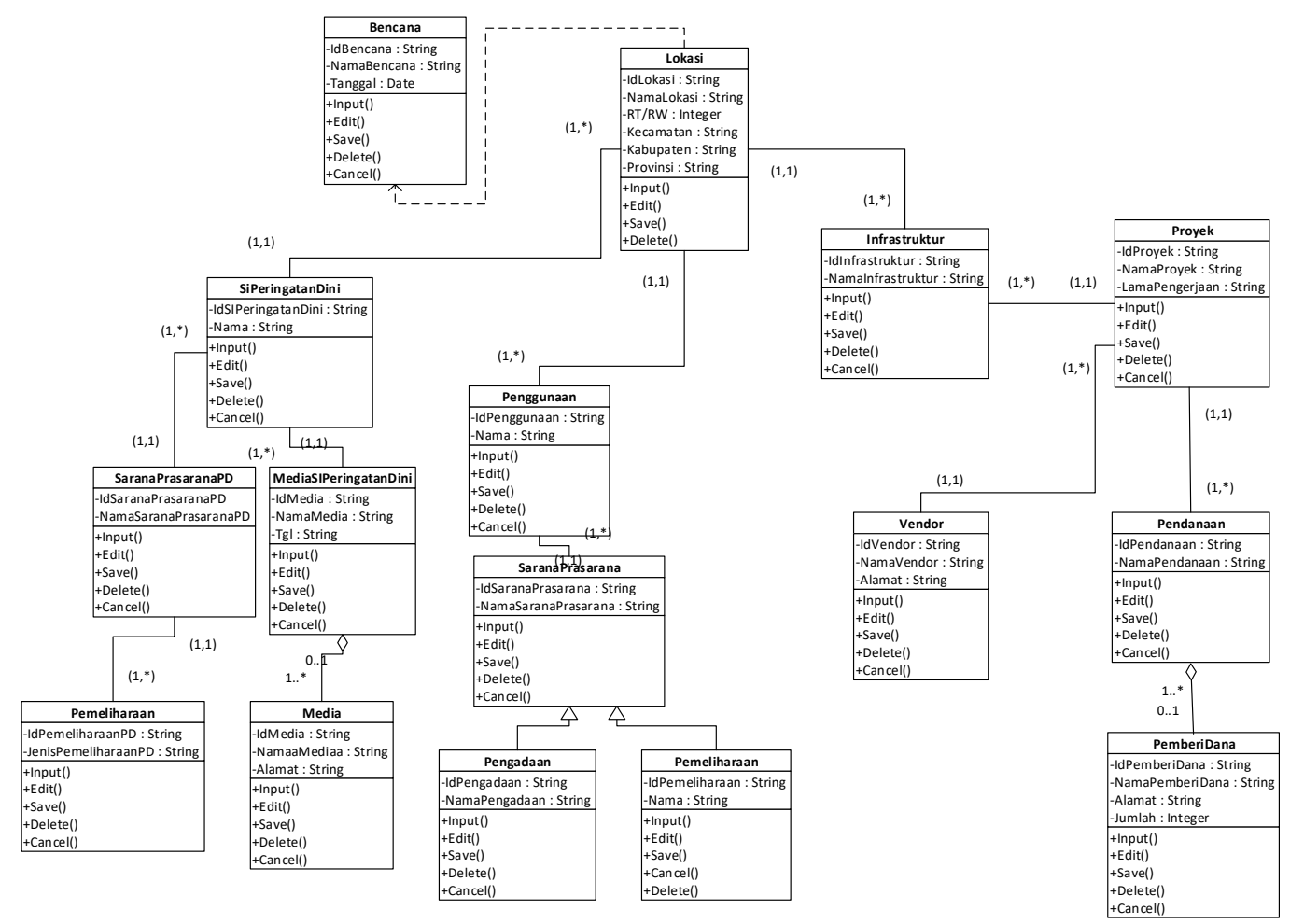

Gambar 4. Class Diagram Sistem Informasi Penanggulangan Bencana

\section{Fase Technology Architecture}

Fase architecture technology bertujuan untuk mengidentifikasi teknologi yang dibutuhkan untuk mendukung pengembangan aplikasi yang akan datang. Teknologi yang dibutuhkan dalam pendefinisian platfrom teknologi adalah teknologi jaringan yang dapat menghubungkan antar aplikasi sehingga ada keterkaitan unit organisasi dan fungsi bisnis di dalam platfrom teknologi tersebut. Secara lengkap, hubungan antara aplikasi yang diusulkan dengan kebutuhan jaringan ditunjukkan pada Tabel 2.

Tabel 2 Hubungan antara aplikasi dan kebutuhan jaringan

\begin{tabular}{|r|l|l|}
\hline \multicolumn{1}{|c|}{ No } & \multicolumn{1}{|c|}{ Nama Aplikasi } & \multicolumn{1}{|c|}{ Kebutuhan Jaringan } \\
\hline 1. & Aplikasi Monitoring dan Peringatan Dini & $\begin{array}{l}\text { Jaringan Internet } \\
\text { Jaringan Satelit } \\
\text { Jaringan Selular } \\
\text { Jaringan Radio } \\
\text { Jaringan Televisi }\end{array}$ \\
\hline 2. & Aplikasi Simulasi dan Asessment Bencana & $\begin{array}{l}\text { Jaringan Internet } \\
\text { Jaringan Mobile Internet }\end{array}$ \\
\hline 3. & Aplikasi GIS(Geography Information Systems) & $\begin{array}{l}\text { Jaringan Internet } \\
\text { Jaringan Mobile Internet }\end{array}$ \\
\hline 4. & Aplikasi Infrastruktur Data Spasial Bencana & $\begin{array}{l}\text { Jaringan Internet } \\
\text { Jaringan Mobile Internet }\end{array}$ \\
\hline 5. & Aplikasi Sistem Logistik & $\begin{array}{l}\text { Jaringan Internet } \\
\text { Jaringan Mobile Internet }\end{array}$ \\
\hline 6. & Aplikasi manajement finansial & $\begin{array}{l}\text { Jaringan Internet } \\
\text { Jaringan Mobile Internet }\end{array}$ \\
\hline
\end{tabular}


Aplikasi yang dibangun diharapkan dapat digunakan pada proses penanggulangan bencana dari lokasi bencana. Karena itu, untuk mengantisipasi tidak adanya koneksi akses internet di lokasi bencana, baik karena rusak akibat bencana maupun karena lokasi bencana yang berada pada daerah terpencil, maka diperlukan sebuah teknologi jaringan menggunakan satelit yang bersifat mobile atau dapat dipasang dan dipindah-pindah dari satu lokasi ke lokasi yang lain. Tipografi jaringan yang diusulkan secara lengkap dapat dilihat pada Gambar 5.

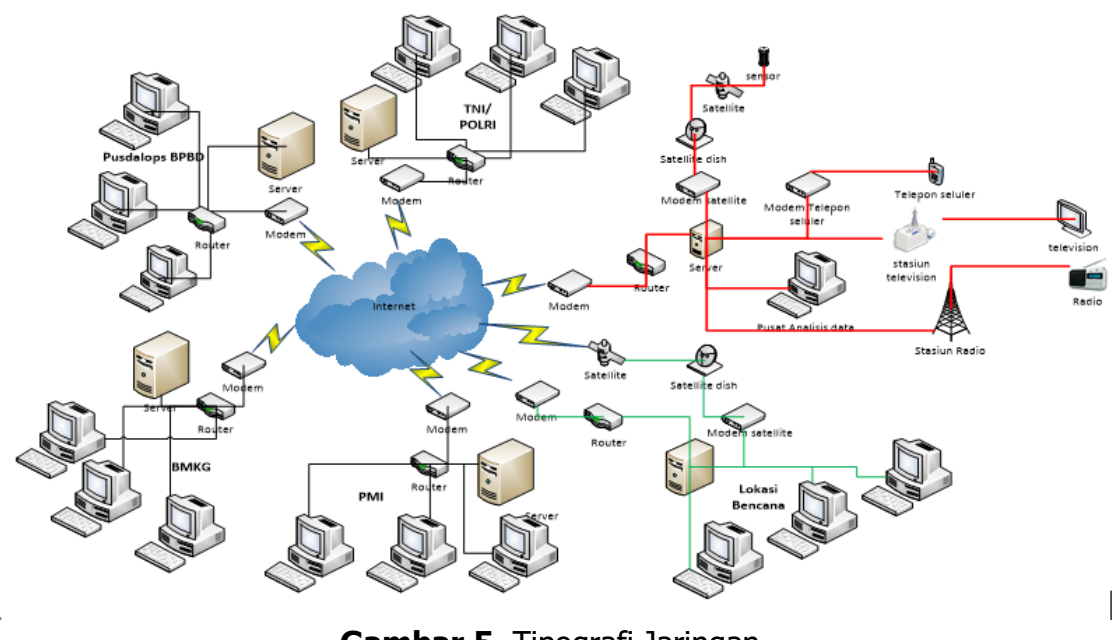

Gambar 5. Tipografi Jaringan

\section{Fase Opportunities and Solution}

Fase ini digunakan untuk membandingkan kondisi yang saat ini dengan kondisi yang ingin dicapai. Langkah ini penting untuk melihat bagian mana dari arsitektur sistem yang ada saat ini yang masih dapat dipertahankan, bagian mana yang perlu dikembangkan dan bagian mana yang benar-benar harus dihilangkan. Hal ini dapat dilakukan dengan melakukan analisa gap antara kondisi yang ada dengan kondisi yang akan datang dan kemudian diikuti dengan langkah-langkah analisa opportunities dan solutions. Analisa gap dilakukan untuk melihat kesenjangan antara kondisi yang ada saat ini (existing) dengan kondisi yang ingin dicapai. Analisa gap ini dilakukan pada masing-masing arsitektur yang ada mulai dari arsitektur aplikasi, arsitektur data, dan arsitektur teknologi. Dengan melakukan analisa gap, organisasi dapat melihat seberapa besar pengembangan sistem informasi yang harus dilakukan untuk mencapai kondisi yang diinginkan organisasi.

\section{Fase Migration Planning}

Tujuan dari tahapan ini adalah merencanakan proses migrasi atau peralihan dari sistem yang lama ke yang baru agar penerapan sistem informasi yang akan dibangun menjadi terarah dan berjalan dengan baik. Proses migrasi meliputi penentuan prioritas project, resourcing dan biaya, dan meminimalisir resiko.

\section{Kesimpulan dan Saran}

Berdasarkan penelitian yang sudah dilakukan pada perencanaan arsitektur enterprise menggunakan metode TOGAF, maka dapat diambil kesimpulan sebagai berikut:

1. Pengembangan sistem informasi penanggulangan bencana perlu dilakukan sebagai solusi terhadap permasalah yang timbul dalam proses penanggulangan bencana. Sistem informasi yang tepat, cepat, akurat dan terintegrasi memungkinkan proses penanggulangan becana dapat dilakukan dengan lebih baik sesuai dengan amanat undang-undang yang berlaku.

2. Teknologi informasi dan komunikasi yang tersedia saat ini memungkinkan sistem informasi menjadi solusi yang tepat terhadap permasalahan dalam proses penanggulangan bencana. 
3. Proses perencanaan arsitektur sistem informasi untuk penanggulangan bencana yang tepat dapat dilakukan dengan menggunakan framework TOGAF ADM. Hasil dari perencanaan arsitektur enterprise tersebut dapat dijadikan sebagai pedoman atau panduan untuk menentukan kebijakan dan membuat bluprint dalam pengembangan sistem informasi penanggulangan bencana.

Adapun saran-saran dari penulis adalah sebagai berikut:

1. Sistem informasi yang akan dikembangkan harus terintegrasi dan dapat memberikan informasi kepada semua pihak yang terkait dalam penanggulangan bencana, sehingga dapat digunakan sebagai dasar pengambilan keputusan.

2. Keberhasilan pengembangan sistem informasi tidak hanya bergantung pada faktor perencanaan arsitektur enterprise yang baik, tetapi juga ditentukan oleh faktor-faktor lain seperti komitmen managemen, kerja sama pegawai dan dukungan dari stakeholder. Faktor-faktor tersebut juga perlu mendapat perhatian ketika pengembangan sistem dilakukan.

3. Penelitian ini hanya dibatasi sampai pada tahap Migrations Planning, untuk perencanaan arsitektur yang lebih lengkap, maka perlu dilanjutkan sampai tahan berikutnya.

\section{Referensi}

1. Hamzah Malikul, Sophan K.M, Kustiyaningsih Yeni, 2012. "Perancangan Sistem Informasi Badan Kepegawaian daerah (BKD) Bangkalan Sebagai Sub Sistem dari E-Govermment Bangkalan Menggunakan TOGAF ADM"

2. CIO Council, 1999. "Federal Enterprise Architecture Framework.Version 1.1" http://www.enterprise-architecture.info/Images/Documents/Federal\%20EA\%20 Framework.pdf. Diakses 12 April 2014

3. BNPB, 2008. "Peraturan Badan Nasional Penanggulangan Bencana No.4/2008 tentang Pedoman penyususnan rencana penanggulangan bencana".

4. Undang-undang republik indonesia nomor 24 tahun 2007 tentang penanggulangan bencana

5. http://www.antarasumbar.com/berita/nasional/d/0/332338/2002-2014-bencana-alam-indonesiacapai-1-093.html, diakses 22 februari 2014. 